\title{
Withdrawal of inhaled corticosteroids versus continuation of triple therapy in patients with COPD in real life: observational comparative effectiveness study
}

Helgo Magnussen ${ }^{1}$, Sarah Lucas ${ }^{2}$, Therese Lapperre, ${ }^{3,4}$, Jennifer K. Quint ${ }^{4}$, Ronald J. Dandurand ${ }^{5}$, Nicolas Roche ${ }^{6}$, Alberto Papi ${ }^{7}$, David Price ${ }^{8,9}$ and Marc Miravitlles ${ }^{10^{*}}$ (D) on behalf of the Respiratory Effectiveness Group (REG)

\begin{abstract}
Background: Inhaled corticosteroids (ICS) are indicated for prevention of exacerbations in patients with COPD, but they are frequently overprescribed. ICS withdrawal has been recommended by international guidelines in order to prevent side effects in patients in whom ICS are not indicated.

Method: Observational comparative effectiveness study aimed to evaluate the effect of ICS withdrawal versus continuation of triple therapy (TT) in COPD patients in primary care. Data were obtained from the Optimum Patient Care Research Database (OPCRD) in the UK.

Results: A total of 1046 patients who withdrew ICS were matched 1:4 by time on TT to 4184 patients who continued with TT. Up to $76.1 \%$ of the total population had 0 or 1 exacerbation the previous year. After controlling for confounders, patients who discontinued ICS did not have an increased risk of moderate or severe exacerbations (adjusted HR: $1.04,95 \%$ confidence interval $(\mathrm{Cl}) 0.94-1.15 ; \mathrm{p}=0.441)$. However, rates of exacerbations managed in primary care (incidence rate ratio (IRR) 1.33, 95\% Cl 1.10-1.60; $p=0.003$ ) or in hospital (IRR $1.72,95 \% \mathrm{Cl} 1.03-2.86 ; p=0.036$ ) were higher in the cessation group. Unsuccessful ICS withdrawal was significantly and independently associated with more frequent courses of oral corticosteroids the previous year and with a blood eosinophil count $\geq 300 \mathrm{cells} / \mathrm{\mu L}$.

Conclusions: In this primary care population of patients with COPD, composed mostly of infrequent exacerbators, discontinuation of ICS from TT was not associated with an increased risk of exacerbation; however, the subgroup of patients with more frequent courses of oral corticosteroids and high blood eosinophil counts should not be withdrawn from ICS.
\end{abstract}

Trial registration European Network of Centres for Pharmacoepidemiology and Pharmacovigilance (EUPAS30851).

Keywords: COPD, Inhaled corticosteroids, Withdrawal, Real life, Effectiveness

*Correspondence: marcm@separ.es

${ }^{10}$ Pneumology Department, Hospital Universitari Vall D'Hebron, Vall D'Hebron Institut de Recerca (VHIR), CIBER de Enfermedades Respiratorias (CIBERES), Vall d'Hebron Barcelona Hospital Campus, Passeig Vall d'Hebron 119-129, 08035 Barcelona, Spain

Full list of author information is available at the end of the article

\section{Background}

Pharmacological therapy for COPD is directed to reduce symptoms, reduce the frequency and severity of exacerbations, and improve exercise tolerance and health status [1]. The mainstay of pharmacological therapy is long-acting bronchodilators, either inhaled long-acting muscarinic antagonists (LAMAs), inhaled long-acting original author(s) and the source, provide a link to the Creative Commons licence, and indicate if changes were made. The images or other third party material in this article are included in the article's Creative Commons licence, unless indicated otherwise in a credit line to the material. If material is not included in the article's Creative Commons licence and your intended use is not permitted by statutory regulation or exceeds the permitted use, you will need to obtain permission directly from the copyright holder. To view a copy of this licence, visit http://creativecommons.org/licenses/by/4.0/. The Creative Commons Public Domain Dedication waiver (http://creativeco mmons.org/publicdomain/zero/1.0/) applies to the data made available in this article, unless otherwise stated in a credit line to the data. 
$\beta 2$-agonists (LABAs), or the combination of both. Inhaled corticosteroids (ICS) can be added to LABA or to the combination of LABA and LAMA leading to triple therapy (TT) in patients with persisting exacerbations despite optimal bronchodilator treatment, particularly if they have high blood eosinophil counts and or history of asthma [1].

A comparison of dual bronchodilation versus TT has been performed predominately in randomised controlled trials (RCT), which have demonstrated the superiority of TT in particular in frequent exacerbators, patients at risk of hospital admission and those with higher concentrations of blood eosinophils [2, 3]. However, there is increasing evidence that patients recruited for RCTs may not completely reflect the characteristics of patients attending in primary care, and therefore, non-interventional, observational studies are important to confirm the findings of RCTs [4]. Regarding efficacy, a large observational study in the UK showed that TT was more effective than dual bronchodilation in preventing exacerbations in patients with increasing blood eosinophil counts and number of previous exacerbations, but not in patients with infrequent exacerbations and low blood eosinophils [5].

Despite the existing evidence and the current recommendations, there is frequent use of TT out of indication, both in primary and secondary care [6-9]. This overuse of ICS and the risks associated with their long-term use, have generated some consensus statements on ICS recommendations for ICS withdrawal [10-15]. These recommendations are based on RCTs, but again, since a significant number of patients in primary care may not be represented in RCTs, it is important to also investigate the possible impact of ICS withdrawal in usual clinical practice.

The current study has used data from a large administrative healthcare database in the UK to investigate the consequences of ICS withdrawal from TT with continuation on dual bronchodilation compared to continuation on TT in patients with COPD followed in primary care.

\section{Methods}

\section{Study design and population}

This was an observational comparative effectiveness study aimed to evaluate the effect of inhaled corticosteroid (ICS) cessation versus continuation of triple therapy in COPD patients.

Exacerbations, symptoms and lung function were compared for a period of 1 year after the index prescription date (IPD), the outcome year, between patients who withdrew and those who continued with ICS in the form of triple therapy. Characteristics of the patients and frequency of exacerbations were collected during the year prior to the IPD, or baseline year.

Patients were required to have $\geq 2$ fixed dose ICS/ LABA and separate LAMA prescriptions, or $\geq 2$ fixed dose ICS/LABA/LAMA prescriptions, in the baseline year. The IPD for the cessation group was the first prescription for a single LABA alongside a single LAMA, or a fixed dose LABA/LAMA, without ICS.

The control group patients were required to have $\geq 1$ fixed or free combination of ICS/LABA/LAMA in the outcome year (Fig. 1). Their IPD was the date when the patient received a repeated prescription for their baseline triple therapy.

Patients were required to have an IPD prior to $1 / 12 / 2018$ to allow for a 1 -year outcome period; in patients with more than one IPD the first IPD was used for analysis.

Data were obtained from the Optimum Patient Care Research Database (OPCRD). The OPCRD contains anonymised, longitudinal medical records for nearly 9 million UK primary care patients, from more than 700 GP practices across the UK. The OPCRD is approved by the Trent Multi-Centre Research Ethics Committee for clinical research use. This study was approved by the Anonymised Data Ethics \& Protocol Transparency committee (ADEPT1419) and registered with the European Network of Centres for Pharmacoepidemiology and Pharmacovigilance (EUPAS30851).

Inclusion criteria were: (A) spirometry-confirmed diagnosis of COPD (Read code and $\mathrm{FEV}_{1} / \mathrm{FVC}<0.7$ within 2 years, ever recorded); (B) aged $\geq 40$ years at IPD; (C) current or ex-smoker; (D) have $\geq 1$ year of continuous patient records in prior to IPD; and (E) ICS medication possession ratio (MPR, (Number of days supplied in period/Days in period) $\times 100) \geq 70 \%$ in the baseline year.

Exclusion criteria were: (A) asthma Read code during the baseline year; (B) prescribed azithromycin or roflumilast or receiving maintenance treatment with systemic steroids. Patients were excluded from the control group if they had ever had an ICS cessation prior to IPD.

\section{Study outcomes}

Outcomes were assessed in the 1-year period following IPD, the outcome year. The primary outcome was time to first COPD exacerbation. An exacerbation was defined as: an unscheduled hospital admission or A\&E attendance for $\mathrm{COPD} /$ respiratory condition or generic hospitalisation code on the same day as a lower respiratory coded consultation, course of oral steroids and/or antibiotics prescribed with lower respiratory consultation. More than one oral steroid course, A\&E attendance, hospitalisation or prescription for antibiotics 


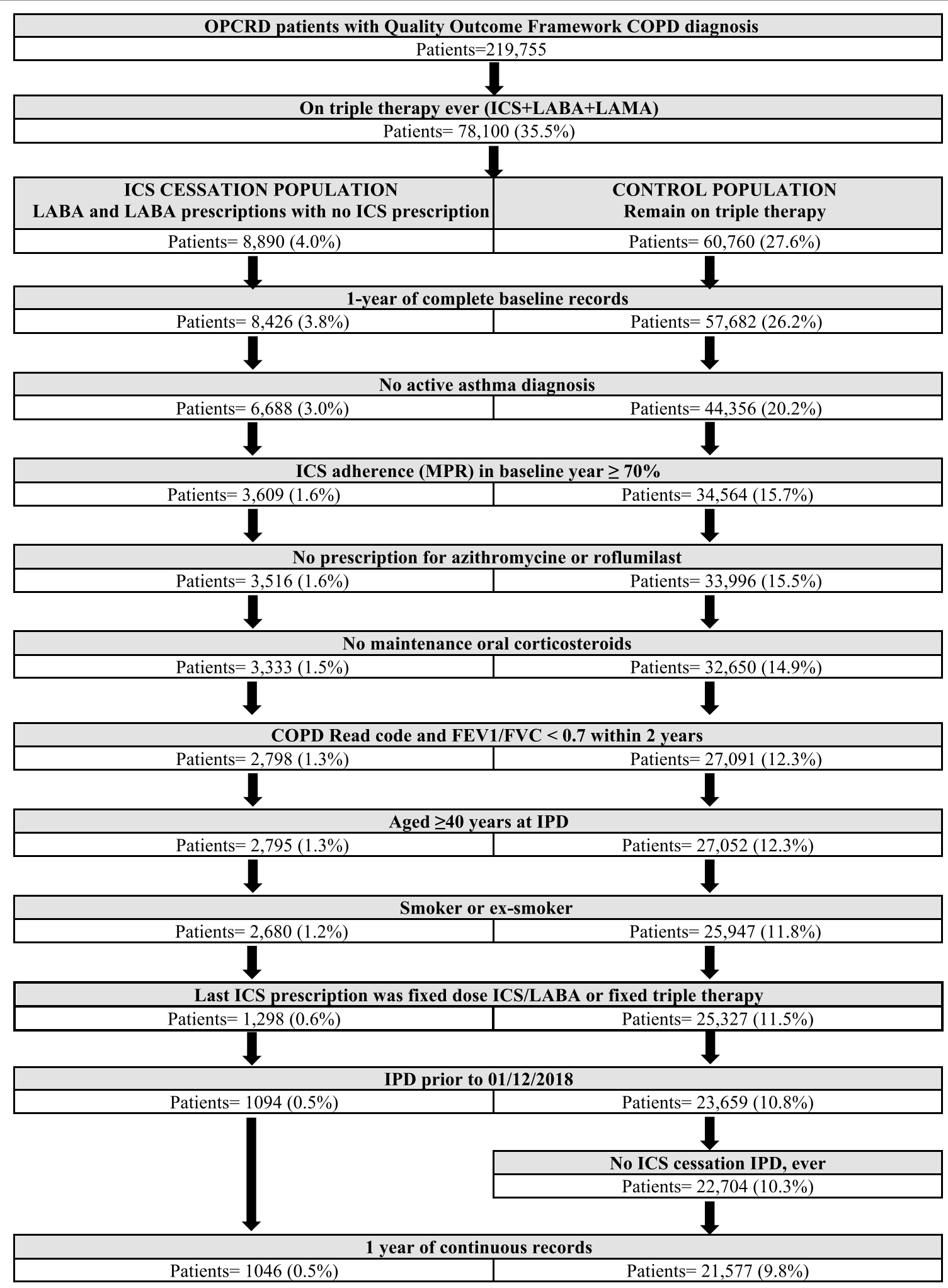

Fig. 1 Patients' flow chart 
occurring within 2 weeks of each other were considered the result of the same exacerbation and were only be counted once.

The secondary outcomes were: exacerbation rate, annualised change in FEV1, where baseline FEV1 was recorded anytime in the baseline year and outcome FEV1 was recorded between 9 and 15 months post IPD; COPD Assessment Test (CAT) score in outcome year; modified Medical Research Council (mMRC) dyspnoea score in the outcome year; time to first consultation with a pneumonia Read code.

\section{Statistical analysis}

In order to select an IPD for the control patients and reduce the risk of survival bias, control patients were selected by matching 1:4 with ICS cessation patients based on time on triple therapy using optimal matching. Intention-to-treat analyses were performed using $\mathrm{R}$ software (www.r-project.org/).

Demographics and clinical characteristics were compared between the ICS cessation and control groups using chi-squared and Mann-Whitney U tests, as appropriate. For all outcomes univariate analyses of the following baseline variables were conducted: age, sex, Body Mass Index (BMI), comorbidities, GOLD stage, smoking status, blood eosinophils, CAT score, mMRC dyspnea score, pre-baseline asthma diagnosis, number of respiratory consultations, exacerbations managed in primary care, exacerbations requiring $A \& E$ attendance or hospitalisation in the baseline year and the numbers of ICS prescriptions, antibiotics prescriptions and oral corticosteroid prescriptions in the baseline year. The time to first exacerbation and time to first pneumonia were analysed using multivariate Cox proportional hazards regression. Exacerbation rate was analysed using multivariate negative binomial regression, change in FEV1 was analysed using multivariate linear regression and changes in CAT scores and mMRC dyspnea were analysed using multivariate logistic regression. Confounding was adjusted for with the use of multivariate analyses. Variables for inclusion in multivariate regression models were selected using fast backwards elimination.

In primary care databases mortality is not well recorded so as a proxy to explore any differences between the ICS cessation and control groups we initially assessed the time until patients left the database; patients may have been recorded as leaving as a result of death or moving to a new practice. No statistically significant difference in time to leaving the database was found between the two groups (Additional file 1: Figure S1), so those who left and lacked a year of continuous records were removed from subsequent analyses.

\section{Results}

\section{Patients' characteristics}

The final dataset consisted of 1046 ICS cessation patients and 21,577 control patients, of whom 4184 were matched for time on triple therapy before IPD and constitute the population of our study (Fig. 1 and Additional file 1: Table S1). There were no significant differences between groups in age, sex distribution, time since COPD diagnosis and smoking status. Patients who had ICS withdrawn had a milder disease with a mean FEV1 (\%) of $58.2 \%$ compared to $53.9 \%(\mathrm{p}=0.003)$, lower concentrations of blood eosinophils $(\mathrm{p}=0.006)$ and had more respiratory consultations and pneumonia coded consultations in Primary Care in the baseline year (both $p=0.001$ ). They also less commonly had a diagnosis of asthma before baseline: $14.1 \%$ versus $26.9 \%(\mathrm{p}<0.001)$. Patient demographics, comorbidities and healthcare and medication utilisation in the baseline year are presented in Tables 1 and 2.

\section{Primary outcome: time to first COPD exacerbation}

The cessation of ICS was not associated with an increased risk of having an exacerbation in the outcome year both in univariate (hazard ratio (HR) 1.02 (95\% confidence interval (CI) $0.92-1.12$ ) and in multivariate analysis controlling for confounders (HR 1.04 (95\% CI 0.94-1.15), $\mathrm{p}=0.441$ ) (Table 3, Fig. 2). Only number of exacerbations managed in primary care and oral corticosteroids prescriptions in baseline year were significantly associated with a reduced time to the first exacerbation in multivariate Cox regression analysis (Table 3).

\section{Secondary outcomes: exacerbations and pneumonia}

In the outcome year 501/1046 (47.9\%) of ICS cessation patients experienced at least one exacerbation, percentage that was almost identical to the $48.0 \%$ observed in control patients who remained on triple therapy (2008/4184). In both groups there were slightly more patients who experienced an exacerbation in the baseline year compared to the outcome year [542 (51.8\%) in the ICS cessation group and 2233 (54.6\%) in control patients].

The rate of exacerbations that were managed in primary care, resulting in A\&E attendance or hospitalisation were slightly higher in the ICS cessation group when compared to the control group (Table 4). The univariate and multivariate comparisons are presented in Table 5 . In multivariate analysis the number of episodes in the ICS cessation group was significantly higher [primary care incidence rate ratio (IRR) 1.33 (95\% CI 1.10-1.60), $\mathrm{p}=0.003$; A\&E attendance or hospitalisation IRR 1.72 (95\% CI 1.03-2.86), $\mathrm{p}=0.036$, Table 5].

In the outcome year 24 (2.3\%) ICS cessation patients had a consultation coded for pneumonia versus $52(5 \%)$ 
Table 1 Patient demographics and clinical characteristics

\begin{tabular}{|c|c|c|c|c|}
\hline & $\begin{array}{l}\text { Total } \\
\text { No. } 5230\end{array}$ & $\begin{array}{l}\text { Control } \\
\text { No. } 4184\end{array}$ & $\begin{array}{l}\text { ICS cessation } \\
\text { No. } 1046\end{array}$ & p-value \\
\hline \multicolumn{5}{|l|}{ Age, years } \\
\hline Mean (SD) & $70.8( \pm 9.9)$ & $70.7( \pm 10.2)$ & $71.0( \pm 8.8)$ & 0.61 \\
\hline \multicolumn{5}{|l|}{ Sex } \\
\hline Female & $2330(44.6 \%)$ & $1872(44.7 \%)$ & $458(43.8 \%)$ & 0.60 \\
\hline Male & $2900(55.4 \%)$ & $2312(55.3 \%)$ & $588(56.2 \%)$ & \\
\hline \multicolumn{5}{|l|}{ BMl category } \\
\hline Mean (SD) & $27.3( \pm 7.6)$ & $27.1( \pm 7.3)$ & $28.1( \pm 8.7)$ & $<0.001$ \\
\hline Missing & $204(3.9 \%)$ & 181 (4.3\%) & $23(2.2 \%)$ & \\
\hline \multicolumn{5}{|l|}{ Smoking status } \\
\hline Current smoker & $1813(34.7 \%)$ & 1467 (35.1\%) & $346(33.1 \%)$ & 0.24 \\
\hline Ex-smoker & $3417(65.3 \%)$ & $2717(64.9 \%)$ & $700(66.9 \%)$ & \\
\hline \multicolumn{5}{|l|}{$\mathrm{FEV}_{1} \%$ predicted } \\
\hline Mean (SD) & $54.8( \pm 22.2)$ & $53.9( \pm 22.5)$ & $58.2( \pm 20.9)$ & 0.003 \\
\hline Missing & 471 (9.0\%) & 417 (10.0\%) & $54(5.2 \%)$ & \\
\hline \multicolumn{5}{|l|}{ Blood eosinophil count } \\
\hline$<0.1$ & $370(8.6 \%)$ & $271(8.0 \%)$ & $99(11.1 \%)$ & 0.006 \\
\hline$\geq 0.1$ to $<0.3$ & 2947 (68.7\%) & $2339(68.8 \%)$ & $608(68.4 \%)$ & \\
\hline$\geq 0.3$ & $970(22.6 \%)$ & $788(23.2 \%)$ & $182(20.5 \%)$ & \\
\hline Missing & $943(18.0 \%)$ & $786(18.8 \%)$ & $157(15.0 \%)$ & \\
\hline \multicolumn{5}{|l|}{ CAT score } \\
\hline Mean (SD) & $16.8( \pm 9.3)$ & $17.1( \pm 9.6)$ & $16.0( \pm 8.5)$ & 0.057 \\
\hline Missing & $4056(77.6 \%)$ & $3370(80.5 \%)$ & $686(65.6 \%)$ & \\
\hline \multicolumn{5}{|l|}{ mMRC dyspnea scale } \\
\hline Mean (SD) & $1.9( \pm 1.0)$ & $1.9( \pm 1.0)$ & $1.8( \pm 0.9)$ & $<0.001$ \\
\hline Missing & $340(6.5 \%)$ & $300(7.2 \%)$ & $40(3.8 \%)$ & \\
\hline \multicolumn{5}{|l|}{ Time since first COPD diagnosis, year } \\
\hline Mean (SD) & $8.5( \pm 6.7)$ & $8.5( \pm 6.8)$ & $8.5( \pm 6.2)$ & 0.37 \\
\hline Missing & $152(2.9 \%)$ & $124(3.0 \%)$ & $28(2.7 \%)$ & \\
\hline \multicolumn{5}{|l|}{ Comorbidities } \\
\hline Asthma (diagnosed pre baseline) ${ }^{a}$ & $1273(24.3 \%)$ & $1126(26.9 \%)$ & $147(14.1 \%)$ & $<0.001$ \\
\hline Asthma (diagnosed in year post IPD) & $18(0.34 \%)$ & $12(0.29 \%)$ & $6(0.57 \%)$ & 0.23 \\
\hline Bronchiectasis & $368(7.0 \%)$ & $304(7.3 \%)$ & $64(6.1 \%)$ & 0.22 \\
\hline Active rhinitis & $1146(21.9 \%)$ & $918(21.9 \%)$ & $228(21.8 \%)$ & 0.93 \\
\hline Nasal polyps & $128(2.4 \%)$ & $105(2.5 \%)$ & $23(2.2 \%)$ & 0.65 \\
\hline Active GERD & $2517(48.1 \%)$ & 1971 (47.1\%) & $546(52.2 \%)$ & 0.003 \\
\hline Cardiovascular disease & $2358(45.1 \%)$ & $1892(45.2 \%)$ & $466(44.6 \%)$ & 0.70 \\
\hline Ischaemic heart disease & $1161(22.2 \%)$ & $935(22.3 \%)$ & $226(21.6 \%)$ & 0.62 \\
\hline Heart failure & $537(10.3 \%)$ & $444(10.6 \%)$ & $93(8.9 \%)$ & 0.11 \\
\hline Myocardial infarction & $591(11.3 \%)$ & $472(11.3 \%)$ & $119(11.4 \%)$ & 0.91 \\
\hline Cerebrovascular disease & $424(8.1 \%)$ & $347(8.3 \%)$ & $77(7.4 \%)$ & 0.34 \\
\hline Hypertension & $2483(47.5 \%)$ & 1961 (46.9\%) & $522(49.9 \%)$ & 0.083 \\
\hline Diabetes & 1040 (19.9\%) & 837 (20.0\%) & $203(19.4 \%)$ & 0.70 \\
\hline Osteoporosis & $682(13.0 \%)$ & $553(13.2 \%)$ & $129(12.3 \%)$ & 0.47 \\
\hline Anxiety and/or depression & $2341(44.8 \%)$ & $1871(44.7 \%)$ & $470(44.9 \%)$ & 0.92 \\
\hline Chronic kidney disease & $861(16.5 \%)$ & $695(16.6 \%)$ & $166(15.9 \%)$ & 0.58 \\
\hline Other chronic diseases & $920(17.6 \%)$ & $768(18.4 \%)$ & $152(14.5 \%)$ & 0.004 \\
\hline
\end{tabular}

${ }^{a}$ Resolved or Read code prior to, but not during, baseline year 
Table 2 Healthcare and medication utilisation in the baseline year

\begin{tabular}{|c|c|c|c|c|}
\hline & $\begin{array}{l}\text { Total } \\
\text { No. } 5230\end{array}$ & $\begin{array}{l}\text { Control } \\
\text { No. } 4184\end{array}$ & $\begin{array}{l}\text { ICS cessation } \\
\text { No. } 1046\end{array}$ & p-value \\
\hline Respiratory consultations in primary care & $3.8( \pm 3.6)$ & $3.7( \pm 3.4)$ & $4.1( \pm 4.0)$ & 0.001 \\
\hline Exacerbations managed in primary care & $1.0( \pm 1.4)$ & $1.0( \pm 1.4)$ & $1.0( \pm 1.3)$ & 0.41 \\
\hline $\begin{array}{l}\text { Exacerbations requiring A\&E attendance or hospitalisa- } \\
\text { tion }\end{array}$ & $0.08( \pm 0.32)$ & $0.08( \pm 0.31)$ & $0.09( \pm 0.35)$ & 0.21 \\
\hline Total exacerbations & $1.1( \pm 1.4)$ & $1.1( \pm 1.4)$ & $1.1( \pm 1.4)$ & 0.68 \\
\hline Pneumonia-coded consultation, $\mathrm{n}(\%)$ & $153(2.9 \%)$ & $101(2.4 \%)$ & $52(5.0 \%)$ & $<0.001$ \\
\hline ICS prescriptions & $11.1( \pm 3.7)$ & $10.9( \pm 3.5)$ & $12.3( \pm 4.3)$ & $<0.001$ \\
\hline ICS adherence (medication possession ratio) & $98.4( \pm 37.9)$ & $96.1( \pm 37.5)$ & $107.8( \pm 38.2)$ & $<0.001$ \\
\hline LABA prescriptions & $11.2( \pm 4.2)$ & $10.8( \pm 3.8)$ & $12.6( \pm 5.1)$ & $<0.001$ \\
\hline LAMA prescriptions & $9.6( \pm 4.7)$ & $9.3( \pm 4.6)$ & $11.1( \pm 4.8)$ & $<0.001$ \\
\hline SABA prescriptions & $11.4( \pm 9.9)$ & $11.4( \pm 9.7)$ & $11.6( \pm 10.5)$ & 0.66 \\
\hline Theophylline prescriptions, n (\%) & $440(8.4 \%)$ & $384(9.2 \%)$ & $56(5.4 \%)$ & $<0.001$ \\
\hline Carbocysteine prescriptions, n (\%) & $1142(21.8 \%)$ & $920(22.0 \%)$ & $222(21.2 \%)$ & 0.62 \\
\hline Antibiotic prescriptions, n (\%) & $2571(49.2 \%)$ & $2078(49.7 \%)$ & $493(47.1 \%)$ & 0.15 \\
\hline Oral corticosteroid prescriptions, n (\%) & $3122(59.7 \%)$ & $2552(61.0 \%)$ & $570(54.4 \%)$ & $<0.001$ \\
\hline
\end{tabular}

Data are means ( \pm standard deviation), unless otherwise specified

in the baseline year. Among control patients 126 (3.0\%) had a pneumonia in the outcome year compared to 101 $(2.4 \%)$ in the baseline year. Having pneumonia in the baseline year increased the risk of having pneumonia in the outcome year; adjusting for this and age, the cessation of ICS was associated with a non-significantly reduced risk of having a consultation coded for pneumonia in the outcome year (HR 0.69 (95\% CI 0.45-1.08), p<0.108) (Fig. 3).

\section{Secondary outcomes: lung function and symptoms}

In 304 (29.1\%) ICS cessation patients and 1149 (27.5\%) control patients who had $\mathrm{FEV}_{1}$ measurements recorded during both the baseline year and between 9 and 15 months post-IPD, the annualised change of FEV1 was not significantly different between groups (ICS cessation $-48.8 \mathrm{~mL}$ (SD: $226 \mathrm{~mL}$ ) versus - 18.8 (SD: $253 \mathrm{~mL}$ ) in control group (Table 4). Results of multivariate analysis adjusted for $\mathrm{FEV}_{1} \%$ predicted recorded at baseline and the total number of exacerbations in the outcome year showed non-significant beta -24.85 (95\% CI -55.55 to 5.84), $\mathrm{p}=0.112$ ) (Table 5).

Using multivariate logistic regression analyses we investigated the odds of a CAT score $\geq 10$ and the odds of a mMRC dyspnoea score $\geq 2$ recorded at any point in the outcome year. Only $14.6 \%$ of patients had a CAT score recorded in the outcome year; of those, $75.6 \%$ of ICS cessation patients had a score $\geq 10$ compared to $76.1 \%$ of control patients (Table 4). The odds of having a CAT score $\geq 10$ in the 1 -year outcome period were not significantly different in the ICS cessation group compared to the control group (adjusted odds ratio (OR) 1.02 (95\% CI $0.60-1.76), p=0.936$, Tables 4 and 5 ). Similarly, $71.1 \%$ of patients had a mMRC score recorded, of those $61.3 \%$ of ICS cessation patients had a score $\geq 2$ compared to $64.4 \%$ of control patients (adjusted OR 0.77 (95\% CI 0.54-1.10), $\mathrm{p}=0.161$, Tables 4 and 5 ). The odds of either a CAT score $\geq 10$ or mMRC score $\geq 2$ was not significantly associated with the time from IPD to when the measurement was recorded or with the total number of exacerbations in the outcome year.

\section{Successful ICS withdrawal}

In the outcome year 3516 (84\%) control patients maintained a medication possession ratio $\geq 70 \%$ with a mean medication possession ratio of $103.9 \%( \pm 44.8)$, and 647 (61.9\%) ICS cessation patients had reinitiated ICS. Among them, 60 (5.7\%) reinitiated ICS within 7 days and 306 (29.3\%) within 30 days (Fig. 4). Interestingly, only 139 cases $(21.5 \%)$ where ICS was reinitiated had an exacerbation recorded prior to, or at the time of ICS reinitiation.

ICS cessation was considered successful if a patient did not have any exacerbations and did not reinitiate ICS treatment in the outcome year. 247 (23.6\%) ICS cessation patients successfully stopped ICS, while the remaining 799 either restarted ICS or experienced at least one exacerbation in the outcome year. In a multivariate logistic regression model, the odds of successful ICS withdrawal were significantly reduced by having a blood eosinophil count $\geq 0.3$ and by having more prescriptions of oral corticosteroids in the year prior to ICS cessation (Table 6). 
Table 3 Cox proportional hazards regression analysis evaluating the effect of ICS cessation and variables associated with the time to first exacerbation in the 1-year outcome period

\begin{tabular}{|c|c|c|c|c|c|c|c|}
\hline \multirow[t]{2}{*}{ Variable } & \multirow[t]{2}{*}{ Total } & \multirow[t]{2}{*}{ Event } & \multicolumn{2}{|c|}{ Univariate } & \multicolumn{2}{|c|}{ Multivariate } & \multirow[t]{2}{*}{ p-value } \\
\hline & & & HR & $95 \% \mathrm{Cl}$ & HR & $95 \% \mathrm{Cl}$ & \\
\hline \multicolumn{8}{|l|}{ Group } \\
\hline Control & 4184 & $2008(47.9 \%)$ & 1 & Ref & & & \\
\hline ICS cessation & 1046 & 501 (47.9\%) & 1.02 & 0.92 to 1.12 & 1.04 & 0.94 to 1.15 & 0.441 \\
\hline \multicolumn{8}{|l|}{ Sex } \\
\hline Female & 2330 & $1190(51.1 \%)$ & 1 & Ref & & & \\
\hline Male & 2900 & $1319(45.5 \%)$ & 0.85 & 0.79 to 0.92 & & & \\
\hline \multicolumn{8}{|c|}{ GOLD severity category } \\
\hline Mild & 525 & $236(44.9 \%)$ & 1 & Ref & & & \\
\hline Moderate & 2173 & $1019(46.9 \%)$ & 1.05 & 0.91 to 1.21 & & & \\
\hline Severe & 1576 & 790 (50.1\%) & 1.15 & 0.99 to 1.33 & & & \\
\hline Very severe & 485 & $258(53.2 \%)$ & 1.26 & 1.06 to 1.51 & & & \\
\hline \multicolumn{8}{|c|}{ Blood eosinophil count } \\
\hline$<0.1$ & 370 & $173(46.7 \%)$ & 1 & Ref & & & \\
\hline$\geq 0.1$ to $<0.3$ & 2947 & $1452(49.3 \%)$ & 1.07 & 0.91 to 1.25 & & & \\
\hline$\geq 0.3$ & 970 & $490(50.5 \%)$ & 1.1 & 0.93 to 1.31 & & & \\
\hline \multicolumn{8}{|l|}{ CAT score } \\
\hline $0-9$ & 275 & $108(39.2 \%)$ & 1 & Ref & & & \\
\hline $10-19$ & 457 & $206(45.1 \%)$ & 1.2 & 0.95 to 1.52 & & & \\
\hline $20-29$ & 318 & 155 (48.7\%) & 1.33 & 1.04 to 1.70 & & & \\
\hline $30-40$ & 124 & $74(59.7 \%)$ & 1.82 & 1.35 to 2.44 & & & \\
\hline \multicolumn{8}{|c|}{ mMRC dyspnea scale } \\
\hline 0 & 292 & $129(44.2 \%)$ & 1 & Ref & & & \\
\hline 1 & 1538 & $686(44.6 \%)$ & 1.04 & 0.86 to 1.25 & & & \\
\hline 2 & 1648 & $830(50.3 \%)$ & 1.2 & 1.00 to 1.44 & & & \\
\hline 3 & 1168 & $579(49.6 \%)$ & 1.19 & 0.98 to 1.44 & & & \\
\hline 4 & 244 & $124(50.8 \%)$ & 1.23 & 0.96 to 1.57 & & & \\
\hline \multicolumn{8}{|c|}{ Asthma diagnosis pre-baseline } \\
\hline No & 3957 & $1864(47.1 \%)$ & 1 & Ref & & & \\
\hline Yes & 1273 & $645(50.6 \%)$ & 1.13 & 1.03 to 1.23 & & & \\
\hline \multicolumn{8}{|c|}{ Respiratory consultations in baseline year } \\
\hline 0 & 179 & $52(29.0 \%)$ & 1 & Ref & & & \\
\hline $1-2$ & 2116 & $777(36.7 \%)$ & 1.33 & 1.00 to 1.76 & & & \\
\hline $3-4$ & 1434 & $677(47.2 \%)$ & 1.84 & 1.39 to 2.44 & & & \\
\hline $5+$ & 1501 & $1003(66.8 \%)$ & 3.33 & 2.52 to 4.40 & & & \\
\hline \multicolumn{8}{|c|}{ Exacerbations managed in primary care in baseline year } \\
\hline 0 & 2573 & $851(33.1 \%)$ & 1 & Ref & & & \\
\hline 1 & 1404 & $732(52.1 \%)$ & 1.81 & 1.64 to 2.00 & 1.74 & 1.57 to 1.93 & $<0.001$ \\
\hline 2 & 637 & $421(66.1 \%)$ & 2.81 & 2.50 to 3.16 & 2.57 & 2.26 to 2.93 & $<0.001$ \\
\hline $3+$ & 616 & $505(81.9 \%)$ & 4.57 & 4.09 to 5.10 & 4.04 & 3.55 to 4.59 & $<0.001$ \\
\hline \multicolumn{8}{|c|}{ Exacerbations requiring A\&E attendance or hospitalisation in baseline year } \\
\hline 0 & 4885 & $2302(47.1 \%)$ & 1 & Ref & & & \\
\hline $1+$ & 345 & $207(60.0 \%)$ & 1.49 & 1.29 to 1.71 & & & \\
\hline \multicolumn{8}{|c|}{ Antibiotics prescriptions in baseline year } \\
\hline 0 & 2659 & $895(33.6 \%)$ & 1 & Ref & & & \\
\hline 1 & 1298 & $682(52.5 \%)$ & 1.81 & 1.64 to 2.00 & & & \\
\hline 2 & 600 & 390 (65.0\%) & 2.6 & 2.31 to 2.93 & & & \\
\hline $3+$ & 673 & $542(80.5 \%)$ & 4.29 & 3.86 to 4.78 & & & \\
\hline
\end{tabular}


Table 3 (continued)

\begin{tabular}{|c|c|c|c|c|c|c|c|}
\hline \multirow[t]{2}{*}{ Variable } & \multirow[t]{2}{*}{ Total } & \multirow[t]{2}{*}{ Event } & \multicolumn{2}{|c|}{ Univariate } & \multicolumn{2}{|c|}{ Multivariate } & \multirow[t]{2}{*}{ p-value } \\
\hline & & & HR & $95 \% \mathrm{Cl}$ & HR & $95 \% \mathrm{Cl}$ & \\
\hline \multicolumn{8}{|c|}{ OCS prescriptions in baseline year } \\
\hline 0 & 2108 & $769(36.5 \%)$ & 1 & Ref & & & \\
\hline 1 & 992 & $454(45.7 \%)$ & 1.34 & 1.19 to 1.50 & 1.02 & 0.90 to 1.15 & 0.791 \\
\hline 2 & 680 & $375(55.1 \%)$ & 1.75 & 1.55 to 1.98 & 1.14 & 1.00 to 1.30 & 0.053 \\
\hline $3+$ & 1450 & $911(62.8 \%)$ & 2.21 & 2.01 to 2.44 & 1.22 & 1.09 to 1.37 & $<0.001$ \\
\hline \multicolumn{8}{|c|}{ ICS medication possession ratio in baseline year } \\
\hline$\geq 70-<80 \%$ & 1559 & $728(46.7 \%)$ & 1 & Ref & & & \\
\hline$\geq 80-<90 \%$ & 1049 & $491(46.8 \%)$ & 1 & 0.90 to 1.13 & 1 & 0.90 to 1.13 & 0.947 \\
\hline$\geq 90-<100 \%$ & 1254 & $599(47.7 \%)$ & 1.05 & 0.94 to 1.17 & 0.99 & 0.88 to 1.10 & 0.804 \\
\hline$\geq 100 \%$ & 1368 & $691(50.5 \%)$ & 1.12 & 1.01 to 1.24 & 1.03 & 0.93 to 1.15 & 0.55 \\
\hline \multicolumn{8}{|c|}{ Time since first COPD diagnosis, year } \\
\hline$<1$ & 321 & $132(41.1 \%)$ & 1 & Ref & & & \\
\hline$\geq 1-<5$ & 1360 & $607(44.6 \%)$ & 1.11 & 0.92 to 1.34 & & & \\
\hline$\geq 5-<10$ & 1741 & $862(49.5 \%)$ & 1.29 & 1.07 to 1.55 & & & \\
\hline$\geq 10-<15$ & 1017 & $502(49.3 \%)$ & 1.29 & 1.07 to 1.56 & & & \\
\hline$\geq 15$ & 639 & $330(51.6 \%)$ & 1.38 & 1.13 to 1.69 & & & \\
\hline \multicolumn{8}{|c|}{ Time on triple therapy, year } \\
\hline$<1$ & 896 & $386(43.1 \%)$ & 1 & Ref & & & \\
\hline$\geq 1-<3$ & 1626 & $739(45.4 \%)$ & 1.1 & 0.97 to 1.24 & & & \\
\hline$\geq 3-<5$ & 1234 & $596(48.3 \%)$ & 1.2 & 1.05 to 1.36 & & & \\
\hline$\geq 5$ & 1474 & 788 (53.4\%) & 1.38 & 1.22 to 1.55 & & & \\
\hline
\end{tabular}

Only variables where univariate analysis gave a $\mathrm{p}$-value $<0.05$ are shown

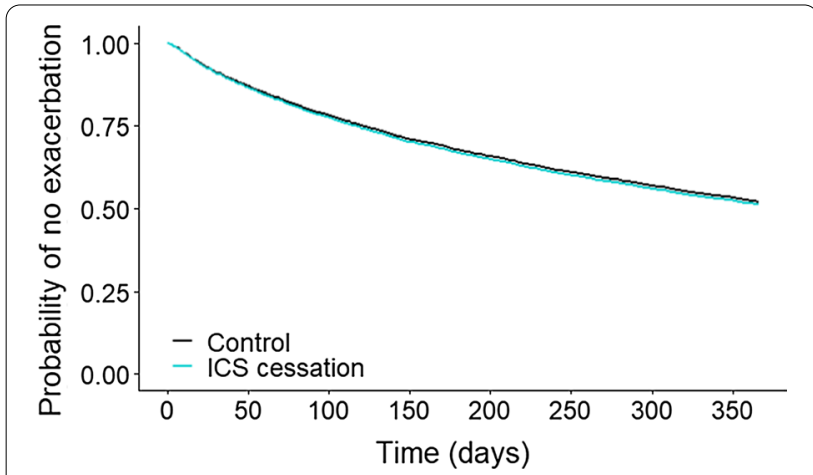

Fig. 2 Plot of multivariate Cox proportional hazards model of time to first exacerbation in the 1 -year outcome period. $\mathrm{HR}=1.04(95 \% \mathrm{Cl}$ $0.94-1.15 ; p=0.441)$

\section{Sensitivity analyses}

In order to analyse the consistency of the findings, we performed some sensitivity analyses of the main outcome in different population of patients with COPD. The first analysis compared time to the first exacerbation in both groups of patients in those individuals who experienced 0 or 1 exacerbation the previous year and those with 2 or more. The second analysis evaluate the effect of ICS withdrawal independently in patients with either mildmoderate or severe-very severe COPD. The third analysis evaluated the risk in patients with a concomitant diagnosis of asthma. The fourth analysed the main outcome separately in patients with blood eosinophil counts below or above 300 cells $/ \mu \mathrm{L}$. The fifth analysed the risk of ICS withdrawal in patients with $<2$ exacerbations and $<300$ eosinophils $/ \mu \mathrm{L}$; and the final analysis investigated the risk of withdrawal excluding control patients with MPR $<70 \%$ and censoring ICS cessation patients who reinitiated ICS prior to their first exacerbation. All these analyses showed no significantly increased risk of exacerbation associated with ICS withdrawal (OR ranging from 0.954 to $1.08, \mathrm{p}>0.05$ in all comparisons) (see Additional file 11 Figures S2-S7).

\section{Discussion}

The present study shows that patients with COPD followed in primary care in the UK did not have an increased risk of exacerbations after withdrawal of ICS as compared to those patients remaining on TT within 1-year of observation. The rates of exacerbations went down in the outcome year compared to the baseline year in both groups of patients; however, the adjusted incidence rate ratio was in favour of ICS continuation, in 
Table 4 Secondary outcomes in the ICS cessation and control groups in the 1-year outcome period

\begin{tabular}{|c|c|c|c|}
\hline & $\begin{array}{l}\text { Total } \\
\text { No. } 5230\end{array}$ & $\begin{array}{l}\text { Control } \\
\text { No. } 4184\end{array}$ & $\begin{array}{l}\text { ICS cessation } \\
\text { No. } 1046\end{array}$ \\
\hline \multicolumn{4}{|l|}{ Exacerbations } \\
\hline Managed in primary care & $0.86( \pm 1.33)$ & $0.86( \pm 1.32)$ & $0.90( \pm 1.35)$ \\
\hline Resulting in A\&E attendance & $0.09( \pm 0.38)$ & $0.09( \pm 0.36)$ & $0.11( \pm 0.45)$ \\
\hline Total exacerbations & $0.96( \pm 1.42)$ & $0.94( \pm 1.41)$ & $1.01( \pm 1.46)$ \\
\hline \multicolumn{4}{|l|}{ Change in $\mathrm{FEV}_{1}$} \\
\hline Baseline FEV1 (L) & $1.39( \pm 0.57)$ & $1.36( \pm 0.56)$ & $1.49( \pm 0.60)$ \\
\hline Outcome FEV1 (L) & $1.35( \pm 0.58)$ & $1.33( \pm 0.58)$ & $1.43( \pm 0.60)$ \\
\hline Annualised change in FEV1 (in $\mathrm{mL}$ ) & $-25.1( \pm 248.1)$ & $-18.8( \pm 253.2)$ & $-48.8( \pm 226.4)$ \\
\hline Missing (n (\%)) & $3777(72.2 \%)$ & 3035 (72.5\%) & $742(70.9 \%)$ \\
\hline \multicolumn{4}{|l|}{ CAT score in outcome year ${ }^{\mathrm{a}}$} \\
\hline$<10$ & $183(24.0 \%)$ & $135(23.9 \%)$ & $48(24.4 \%)$ \\
\hline$\geq 10$ & $580(76.0 \%)$ & $431(76.1 \%)$ & $149(75.6 \%)$ \\
\hline Mean (SD) & $16.6( \pm 9.6)$ & $16.8( \pm 9.9)$ & $16.2( \pm 8.8)$ \\
\hline Missing & $4467(85.4 \%)$ & $3618(86.5 \%)$ & $849(81.2 \%)$ \\
\hline \multicolumn{4}{|l|}{ mMRC dyspnea score in outcome year ${ }^{a}$} \\
\hline $0-1$ & $1345(36.2 \%)$ & $1072(35.6 \%)$ & $273(38.7 \%)$ \\
\hline $2-4$ & $2371(63.8 \%)$ & 1938 (64.4\%) & $433(61.3 \%)$ \\
\hline Mean (SD) & $1.9( \pm 1.0)$ & $2.0( \pm 1.0)$ & $1.9( \pm 1.0)$ \\
\hline Missing & 1514 (28.9\%) & $1174(28.1 \%)$ & $340(32.5 \%)$ \\
\hline
\end{tabular}

${ }^{\text {a }}$ First score recorded following IPD is used. Values given are mean (SD)

Table 5 Univariate and multivariate analysis of the effects of ICS cessation compared to continuing triple therapy on secondary outcomes in the outcome year

\begin{tabular}{|c|c|c|c|c|c|c|}
\hline & \multicolumn{3}{|c|}{ Univariate analysis } & \multicolumn{3}{|c|}{ Multivariate analysis } \\
\hline & IRR & $95 \% \mathrm{Cl}$ & p-value & IRR & $95 \% \mathrm{Cl}$ & p-value \\
\hline \multicolumn{7}{|l|}{ Exacerbation rate } \\
\hline Managed in primary care & 1.05 & 0.95 to 1.17 & 0.330 & 1.33 & 1.10 to 1.60 & 0.003 \\
\hline \multirow[t]{2}{*}{ Resulting in A\&E attendance } & 1.24 & 0.95 to 1.62 & 0.109 & 1.72 & 1.03 to 2.86 & 0.036 \\
\hline & B coef & $95 \% \mathrm{Cl}$ & p-value & B coef & $95 \% \mathrm{Cl}$ & p-value \\
\hline \multirow[t]{2}{*}{ Change in FEV1 } & -30.03 & -61.39 to 1.33 & 0.061 & -24.85 & -55.55 to 5.84 & 0.112 \\
\hline & OR & $95 \% \mathrm{Cl}$ & p-value & OR & $95 \% \mathrm{Cl}$ & p-value \\
\hline \multicolumn{7}{|l|}{ CAT score } \\
\hline$\geq 10$ & 0.97 & 0.67 to 1.43 & 0.884 & 1.02 & 0.60 to 1.76 & 0.936 \\
\hline \multicolumn{7}{|l|}{ mMRC dyspnea score } \\
\hline$\geq 2$ & 0.88 & 0.74 to 1.04 & 0.129 & 0.77 & 0.54 to 1.10 & 0.161 \\
\hline
\end{tabular}

particular for the exacerbations resulting in secondary care. It is noteworthy that ICS cessation group had higher respiratory and pneumonia-coded consultations in primary care in the baseline year. The risk of reinitiating ICS or suffering an exacerbation in the withdrawal group was significantly increased in patients with blood eosinophil counts $\geq 300$ cells $/ \mu \mathrm{L}$ and in those having more prescriptions of oral corticosteroids in the year prior to
ICS cessation. No significant differences in the changes in FEV1, CAT scores or mMRC dyspnoea score between patients who discontinued ICS and those who continued with TT were observed.

There is still a controversy about the rationale for use of ICS in COPD [16]. Current recommendations indicate that ICS should be given in combination with long-acting bronchodilators for patients with frequent or severe 


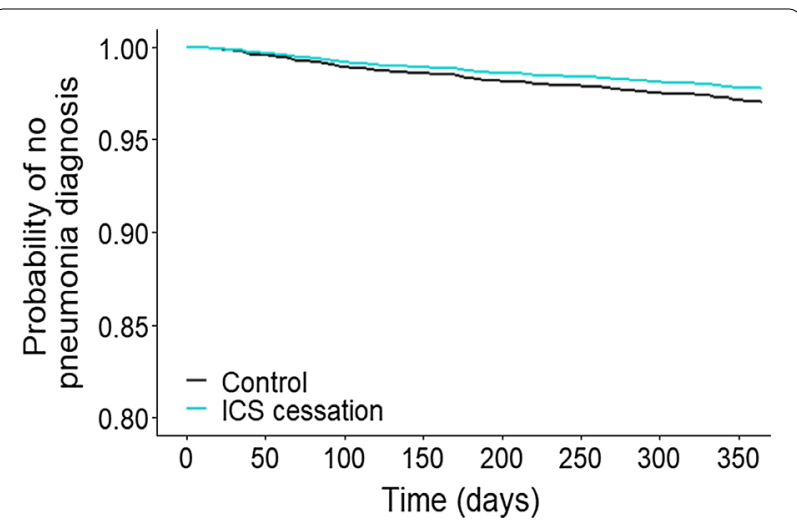

Fig. 3 Plot of multivariate Cox proportional hazards model of time to first consultation for pneumonia in the 1-year outcome period. $H R=0.69(95 \% \mathrm{Cl} 0.45$ to $1.08 ; p=0.108)$

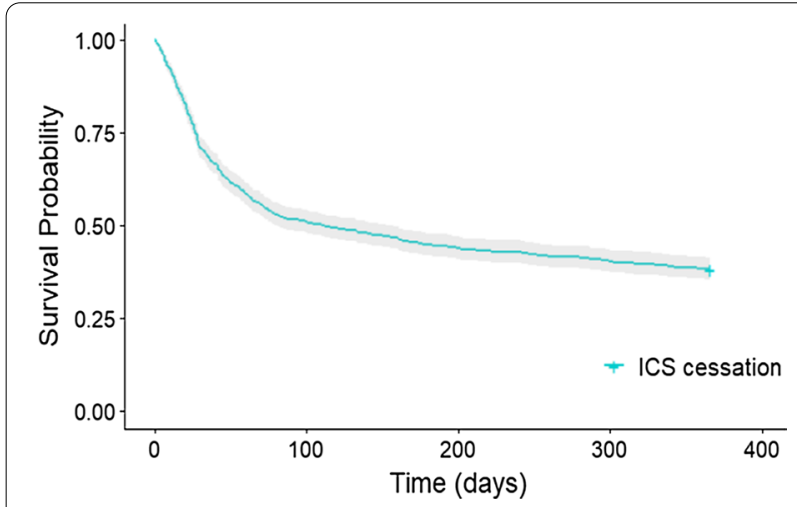

Fig. 4 Time to reinitiation of ICS

exacerbations and increased eosinophilic profile [1]. These patients represent only approximately one fourth to one third of the patients attending primary care, as shown in large studies that identified around $25 \%$ of patients with a frequent exacerbator phenotype $[17,18]$ and between 20 and $30 \%$ with a blood eosinophil count higher than 300 cells/mL [19]. However, several studies in different countries have shown an excessive use of ICS outside the current indications; a recent study in the UK showed that $13.7 \%$ of GOLD A and $26.2 \%$ of GOLD B received TT [7]; similarly, data from Switzerland observed a use of TT in 13.8\% of GOLD A and $28.2 \%$ of GOLD B patients [6]. This excessive use of ICS in primary care may be explained, at least in part, by the difficulties in differentiating asthma from COPD or by the inadequate consideration of the history of exacerbations, the peripheral blood eosinophil counts or the risk of community-acquired pneumonia [20,21].

Since the inadequate long-term use of ICS is associated with increased risk of side effects, it is important to identify patients in whom the risk/benefit ratio clearly supports the use of these drugs. Furthermore, in the case of patients inadequately treated with ICS, it is important to investigate the possible risk associated with the withdrawal of ICS.

Early trials investigating the risks associated with withdrawal of ICS provided conflicting results, basically due to small sample sizes, different inclusion criteria and, more importantly, due to insufficient or inadequate alternative treatments after ICS discontinuation [22]. The more recent randomised control trials (RCT) designed to investigate the risks associated with discontinuation of ICS compared patients on TT with those withdrawing ICS and continuing on dual bronchodilation as alternative. One trial included patients with severe airflow limitation (FEV $1<50 \%$ predicted) and a history of at least one exacerbation during the year prior to enrolment [23]. ICS withdrawal did not lead to an increased number of COPD exacerbations compared to continued ICS users. ICS withdrawal led to a statistically significant decrease of lung function, which was not clinically relevant and a subsequent post-hoc analysis showed that the rate of decline of lung function was no different in patients who discontinued or in patients who continued ICS [24]. Another post-hoc analysis found that discontinuation of ICS was associated with an increased rate of moderate or severe exacerbations in the smaller subgroup of patients with eosinophil counts of $\geq 300$ cells $/ \mu \mathrm{L}$ or $4 \%$ or greater, whereas there was no difference in exacerbation rate in the remaining patients [25].

Another trial studied the effects of ICS abrupt withdrawal in COPD patients with an FEV1 $50-80 \%$ predicted and a history of at least one exacerbation over the preceding year and who received TT for at least 6 months [26]. Similarly to the previous trial [24], no difference was observed in the rate of exacerbations after ICS withdrawal, and only a small reduction of FEV1 was observed in the ICS withdrawal group. Only in the $25 \%$ of patients with blood eosinophil count $\geq 300$ cells $/ \mu \mathrm{L}$, the number of moderate and severe COPD exacerbations was significantly higher following ICS withdrawal [26].

These two large studies were the basis of the American Thoracic Society (ATS) guidelines, which indicates a conditional recommendation for ICS withdrawal for patients with COPD receiving TT if the patient has had no exacerbations in the past year [14]. Similarly, the European Respiratory Society (ERS) has issued a conditional recommendation for the withdrawal of ICS in patients with COPD without a history of frequent exacerbations and a strong recommendation not to withdraw ICS in patients who have a blood eosinophil count $\geq 300$ eosinophils $/ \mu \mathrm{L}$, with or without a history of frequent exacerbations [15]. 
Table 6 Determinants of successful ICS cessation

\begin{tabular}{|c|c|c|c|c|c|c|c|c|}
\hline \multirow[t]{2}{*}{ Variable } & \multirow[t]{2}{*}{ Total } & \multirow[t]{2}{*}{ Event } & \multicolumn{3}{|c|}{ Univariate analysis } & \multicolumn{3}{|c|}{ Multivariate analysis } \\
\hline & & & HR & $95 \% \mathrm{Cl}$ & p-value & HR & $95 \% \mathrm{Cl}$ & p-value \\
\hline \multicolumn{9}{|c|}{ Asthma diagnosis pre-baseline } \\
\hline No & 899 & $223(24.8 \%)$ & & Ref & & & & \\
\hline Yes & 147 & $24(16.3 \%)$ & 0.59 & 0.37 to 0.94 & 0.026 & & & \\
\hline \multicolumn{9}{|c|}{ Blood eosinophil count } \\
\hline$<0.1$ & 99 & 27 (27.2\%) & & Ref & & & & \\
\hline$\geq 0.1$ to $<0.3$ & 608 & $145(23.8 \%)$ & 0.84 & 0.52 to 1.35 & 0.462 & 0.76 & 0.47 to 1.27 & 0.282 \\
\hline$\geq 0.3$ & 182 & $31(17.0 \%)$ & 0.55 & 0.30 to 0.99 & 0.044 & 0.50 & 0.27 to 0.91 & 0.023 \\
\hline \multicolumn{9}{|c|}{ Exacerbations managed in primary care in baseline year } \\
\hline 0 & 535 & $171(31.9 \%)$ & & Ref & & & & \\
\hline 1 & 258 & $55(21.3 \%)$ & 0.58 & 0.41 to 0.82 & 0.002 & & & \\
\hline 2 & 119 & $12(10.1 \%)$ & 0.24 & 0.13 to 0.45 & $<0.001$ & & & \\
\hline $3+$ & 134 & $9(6.7 \%)$ & 0.15 & 0.08 to 0.31 & $<0.001$ & & & \\
\hline \multicolumn{9}{|c|}{ Antibiotic prescriptions in baseline year } \\
\hline 0 & 553 & $175(31.6 \%)$ & & Ref & & & & \\
\hline 1 & 243 & $51(20.9 \%)$ & 0.57 & 0.40 to 0.82 & 0.002 & & & \\
\hline 2 & 107 & $9(8.4 \%)$ & 0.20 & 0.10 to 0.40 & $<0.001$ & & & \\
\hline $3+$ & 143 & $12(8.4 \%)$ & 0.20 & 0.11 to 0.37 & $<0.001$ & & & \\
\hline \multicolumn{9}{|c|}{ OCS prescriptions in baseline year } \\
\hline 0 & 476 & $155(32.5 \%)$ & & Ref & & & & \\
\hline 1 & 183 & $46(25.1 \%)$ & 0.70 & 0.47 to 1.02 & 0.064 & 0.70 & 0.45 to 1.05 & 0.090 \\
\hline 2 & 116 & $13(11.2 \%)$ & 0.26 & 0.14 to 0.48 & $<0.001$ & 0.23 & 0.11 to 0.44 & $<0.001$ \\
\hline $3+$ & 271 & $33(12.2 \%)$ & 0.29 & 0.19 to 0.43 & $<0.001$ & 0.31 & 0.19 to 0.47 & $<0.001$ \\
\hline
\end{tabular}

These guidelines are based on the results of RCTs and derived from well- characterized study populations, which may not always represent the general patient population [4]. Therefore, high quality observational studies including all types of patients attended in primary care are useful to complement the findings obtained in RCTs. In this context, our study has analysed data on 1046 patients who discontinued ICS, matched 1:4 for time on TT with 4184 controls who continued on TT over a period of 1 year of observation. As in the majority of studies in primary care, more than three quarters (76.1\%) of patients were infrequent exacerbators, and the results showed that patients who had withdrawn ICS did not have an increased risk of exacerbation, without any differences in changes in FEV1, CAT scores and mMRC degree of dyspnoea.

Our results are concordant with those obtained in other previous observational studies. Rossi et al. [27] investigated the results of withdrawal of ICS in real life in COPD patients with FEV1 $>50 \%$ and less than two exacerbations per year. Their results showed no differences in lung function, symptoms and exacerbations between patients who withdrew or continued ICS within a 6-month observation period. In an observational study conducted in primary and secondary care in Germany
[28], patients who discontinued ICS at study entry did not have a different risk of exacerbations over a 2-year observation period. Using data from the Clinical Practice Research Datalink (CPRD) in the UK, Oshagbemi et al. [29] did not observe any increase in risk of moderate or severe exacerbations or mortality in a population of $+40,000$ COPD patients in primary care irrespective of the blood eosinophil counts. Finally, in a retrospective study on the effect of withdrawal of ICS after hospitalisation for COPD in Japan, Jo et al. [30] observed a reduced incidence of re-hospitalisation for COPD exacerbations or death in patients who withdraw ICS.

Although ICS withdrawal was not associated with increased risk of exacerbation for the whole group, the rate of exacerbations was slightly higher in the withdrawal group; these findings suggest that there might be a small subgroup of patients who are susceptible to discontinuation and had repeated episodes during the outcome year. Our definition of successful discontinuation of ICS included those patients who did not experience any exacerbation and did not reinitiate ICS during the outcome year. It is possible that not all reinitiations of ICS were due to clinical deterioration. In fact, only $21.5 \%$ cases of reinitiation had an exacerbation recorded prior to, or at the time of ICS reinitiation (see Figs. 2 and 
4). Furthermore, having an exacerbation after ICS withdrawal may not always mean an unsuccessful discontinuation, because the patient may have also had one or more exacerbations the previous year while on ICS. In any case, with this conservative definition, the risk of unsuccessful ICS withdrawal was significantly increased only in patients with blood eosinophil counts $\geq 300$ cells $/ \mu \mathrm{L}$ and in those having more prescriptions of oral corticosteroids in the year prior to ICS cessation. These results support the ATS and particularly the ERS guidelines that recommend discontinuation of ICS in patients without a history of frequent exacerbations and blood eosinophils $<300$ cells $/ \mu \mathrm{L}[14,15]$.

Despite the published studies and recommendations, ICS withdrawal is very infrequent in real life in primary care [31, 32]. In our study, only $2 \%$ of patients on TT discontinued ICS during 1 year, which is similar to the $2 \%$ to $3.5 \%$ rates of discontinuation of ICS observed between 2014 and 2018 in another large primary care study in the UK [33]. However, other studies have observed higher rates, such as the $15 \%$ observed in a population-based study on $+34,000$ patients on TT in primary care in Spain [34] or the $16 \%$ in Korea [35].

A reduction in the risk of pneumonia has been demonstrated after discontinuation of ICS in large population-based studies, and this risk drops especially during the first 3 months after discontinuation [36]. We have also observed a reduced risk of pneumonia in patients who withdraw ICS, although the reduction was not statistically significant probably due to the low number of events registered.

Our study has some limitations, inherent to the observational design: Firstly, although patients who discontinued ICS were milder in terms of airflow obstruction, they had more frequent exacerbations the baseline year compared to those who continued ICS, and could, therefore be more prone to suffer exacerbations in the outcome year, biasing the results against the safety of withdrawal. Secondly, although the analysis controlled for confounders, the observational design is not completely free from bias. Thirdly, our observations on the evolution of CAT scores, FEV1 and mMRC were based on the small subgroup of patients with at least two measurements; however, the results of all these variables were consistent with each other.

In summary, discontinuation of ICS from TT is still very infrequent in primary care. We have not observed an increased risk of exacerbations after discontinuation of ICS in our cohort of mainly infrequent exacerbators; However, there was an increased risk of unsuccessful ICS discontinuation in patients with frequent exacerbations and high blood eosinophil levels, which resulted in an increased rate of exacerbation for the overall withdrawal group. Our results support the recommendations that withdrawal of ICS should be considered in patients with COPD without a history of frequent exacerbations and low blood eosinophil counts.

\section{Conclusions}

In this primary care population of patients with COPD, composed mostly of infrequent exacerbators, discontinuation of ICS from TT was not associated with an increased risk of exacerbation; however, according with current guidelines, the subgroup of patients with more frequent courses of oral corticosteroids in the past year and high blood eosinophil counts should not be withdrawn from ICS.

\section{Supplementary Information}

The online version contains supplementary material available at https://doi. org/10.1186/s12931-021-01615-0.

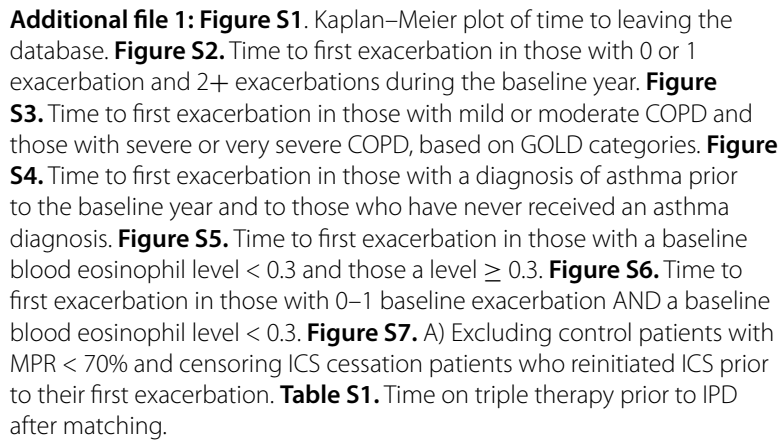

\section{Abbreviations}

ADEPT: Anonymised Data Ethics \& Protocol Transparency; A\&E: Accident and emergency; ATS: American Thoracic Society; BMI: Body mass index; CAT: COPD Assessment Test; Cl: Confidence interval; CPRD: Clinical Practice Research Datalink; COPD: Chronic obstructive pulmonary disease; EUPAS: European Network of Centres for Pharmacoepidemiology and Pharmacovigilance; ERS: European Respiratory Society; FEV $_{1}$ : Forced expiratory volume in $1 \mathrm{~s}$; FVC: Forced vital capacity; GOLD: Global strategy for Obstructive Lung Disease; GP: General practice; HR: Hazard ratio; ICS: Inhaled corticosteroid; IPD: Index prescription date; IRR: Incidence rate ratio; LABA: Long-acting beta-2 agonist; LAMA: Long-acting antimuscarinic agent; mMRC: Modified Medical Research Council dispnea scale; MPR: Medication possession ratio; OPCRD: Optimum Patient Care Research Database; OR: Odds ratio; REG: Respiratory Effectiveness Group; RCT: Randomised clinical trial; TT: Triple therapy; UK: United Kingdom.

\section{Acknowledgements}

The study was designed and conducted by the Respiratory Effectiveness Group (REG; www.regresearchnetwork.org; Ely, UK) and data was delivered by Optimum Patient Care (OPC; www.optimumpatientcare.org) with support from Derek Skinner.

\section{Authors' contributions}

$H M, S L, D P$ and MM were responsible for the concept and design of the study; $\mathrm{SL}$ analysed the data and $\mathrm{HM}$ and MM oversaw all analyses; HM, SL, TL, JKQ $\mathrm{RJD}, \mathrm{NR}, \mathrm{AP}, \mathrm{DP}$ and MM were responsible for data interpretation; MM, HM and $\mathrm{SL}$ drafted the manuscript; TL, JKQ, RJD, NR, AP and DP revised the manuscript critically for intellectual content. All authors have approved the final version to be published and are jointly accountable for all aspects of the work. All authors read and approved the final manuscript. 


\section{Funding}

The study was funded by a Grant from Boehringer Ingelheim.

\section{Availability of data and materials}

The datasets generated and/or analysed during the current study are not publicly available.

\section{Ethics approval and consent to participate}

The OPCRD is approved by the Trent Multi-Centre Research Ethics Committee for clinical research use. This study was approved by the Anonymised Data Ethics \& Protocol Transparency committee (ADEPT1419). Since the study included retrospective anonymised data, no informed consent was required.

\section{Consent for publication}

Not applicable.

\section{Competing interests}

Helgo Magnussen reports personal fees from Boehringer Ingelheim during the conduct of the study and personal fees from AstraZeneca, Novartis, and ndd Medical Technologies, Inc. outside the submitted work. Marc Miravitlles has received speaker fees from AstraZeneca, Boehringer Ingelheim, Chiesi, Cipla, Menarini, Rovi, Bial, Sandoz, Zambon, CSL Behring, Grifols and Novartis, consulting fees from AstraZeneca, Boehringer Ingelheim, Chiesi, GlaxoSmithKline, Bial, Gebro Pharma, Kamada, CSL Behring, Laboratorios Esteve, Ferrer, Mereo Biopharma, Verona Pharma, TEVA, Spin Therapeutics, pH Pharma, Novartis, Sanofi and Grifols and research grants from GlaxoSmithKline and Grifols. Sarah Lucas is an employee of the Respiratory Effectiveness Group, who received funding from Boehringer Ingelheim for conducting this study. Jennifer Quint has received grants from The Health Foundation, MRC, GSK, Bayer, BI, British Lung Foundation, IQVIA, Chiesi AZ, Insmed and Asthma UK outside the submitted work; grants and personal fees from GlaxoSmithKline, Boehringer Ingelheim, AstraZeneca, Bayer, Insmed. Ronald J. Dandurand has received research grants from AstraZeneca Boehringer Ingelheim, GlaxoSmithKline, Novatis, Pfizer and Teva Pharma, consulting fees from Boehringer Ingelheim and Grifols, and speaking fees from Boehringer Ingelheim and Novartis, Nicolas Roche reports grants and personal fees from Boehringer Ingelheim, Novartis, Pfizer and personal fees from Teva, GSK, AstraZeneca, Chiesi, Sanofi, Trudell, Zambon. David Price has board membership with Amgen, AstraZeneca, Boehringer Ingelheim, Chiesi, Circassia, Mylan, Mundipharma, Novartis, Regeneron Pharmaceuticals, Sanofi Genzyme, Teva Pharmaceuticals, Thermofisher; consultancy agreements with Amgen, AstraZeneca, Boehringer Ingelheim, Chiesi, GlaxoSmithKline, Mylan, Mundipharma, Novartis, Pfizer, Teva Pharmaceuticals, Theravance; grants and unrestricted funding for investigatorinitiated studies (conducted through Observational and Pragmatic Research Institute Pte Ltd) from AstraZeneca, Boehringer Ingelheim, Chiesi, Circassia, Mylan, Mundipharma, Novartis, Pfizer, Regeneron Pharmaceuticals, Respiratory Effectiveness Group, Sanofi Genzyme, Teva Pharmaceuticals, Theravance, UK National Health Service; payment for lectures/speaking engagements from AstraZeneca, Boehringer Ingelheim, Chiesi, Cipla, GlaxoSmithKline, Kyorin, Mylan, Mundipharma, Novartis, Regeneron Pharmaceuticals, Sanofi Genzyme, Teva Pharmaceuticals; payment for the development of educational materials from Mundipharma, Novartis; payment for travel/accommodation/ meeting expenses from AstraZeneca, Boehringer Ingelheim, Mundipharma, Mylan, Novartis, Thermofisher; funding for patient enrolment or completion of research from Novartis; stock/stock options from AKL Research and Development Ltd which produces phytopharmaceuticals; owns $74 \%$ of the social enterprise Optimum Patient Care Ltd (Australia and UK) and $74 \%$ of Observational and Pragmatic Research Institute Pte Ltd (Singapore); $5 \%$ shareholding in Timestamp which develops adherence monitoring technology; is peer reviewer for grant committees of the Efficacy and Mechanism Evaluation programme, and Health Technology Assessment; and was an expert witness for GlaxoSmithKline.

\footnotetext{
Author details

${ }_{1}$ Pulmonary Research Institute at Lung Clinic Grosshansdorf, Airway Research Center North, Member of the German Center of Lung Research, Grosshansdorf, Germany. ${ }^{2}$ Respiratory Effectiveness Group, Ely, UK. ${ }^{3}$ Department of Respiratory Medicine, Antwerp University Hospital, Edegem, Denmark. ${ }^{4}$ Laboratory of Experimental Medicine and Paediatrics, University of Antwerp, Wilrijk, UK. ${ }^{5}$ CIUSSS de L'Ouest-de-Lîle-de-Montréal, Montreal Chest Institute, Meakins-Christie Laboratories, Oscillometry Unit and Centre for Innovative
}

Medicine, McGill University Health Centre and Research Institute, Montreal, QC, Canada. ${ }^{6}$ Department of Respiratory Medicine, APHP-Centre University of Paris, UMR1016, Cochin Institute, Paris, France. ${ }^{7}$ Section of Cardiorespiratory and Internal Medicine, Department of Medical Sciences, University of Ferrara, Ferrara, Italy. ${ }^{8}$ Observational and Pragmatic Research Institute, Singapore, Singapore. ${ }^{9}$ Centre of Academic Primary Care, Division of Applied Health Sciences, University of Aberdeen, Aberdeen, UK. ${ }^{10}$ Pneumology Department, Hospital Universitari Vall D'Hebron, Vall D'Hebron Institut de Recerca (VHIR), CIBER de Enfermedades Respiratorias (CIBERES), Vall d'Hebron Barcelona Hospital Campus, Passeig Vall d'Hebron 119-129, 08035 Barcelona, Spain.

Received: 17 November 2020 Accepted: 6 January 2021

Published online: 21 January 2021

\section{References}

1. Singh D, Agusti A, Anzueto A, Barnes PJ, Bourbeau J, Celli BR, et al. Global strategy for the diagnosis, management, and prevention of chronic obstructive lung disease: the GOLD science committee report 2019. Eur Respir J. 2019;53(5).

2. Lipson DA, Barnhart F, Brealey N, Brooks J, Criner GJ, Day NC, et al. Oncedaily single-inhaler triple versus dual therapy in patients with COPD. N Engl J Med. 2018;378(18):1671-80.

3. Cazzola M, Rogliani P, Calzetta L, Matera MG. Triple therapy versus single and dual long-acting bronchodilator therapy in COPD: a systematic review and meta-analysis. Eur Respir J. 2018; 52(6).

4. Roche N, Anzueto A, Bosnic Anticevich S, Kaplan A, Miravitlles M, Ryan $D$, et al. Connected real-life research, a pillar of P4 medicine. Eur Respir $J$. 2020; 55(1).

5. Voorham J, Corradi M, Papi A, Vogelmeier CF, Singh D, Fabbri LM, et al. Comparative effectiveness of triple therapy versus dual bronchodilation in COPD. ERJ Open Res. 2019:5(3):00106-2019.

6. Grewe FA, Sievi NA, Bradicich M, Roeder M, BrackT, Brutsche MH, et al. Compliance of pharmacotherapy with GOLD guidelines: a longitudinal study in patients with COPD. Int J Chron Obstruct Pulmon Dis. 2020;15:627-35.

7. Halpin DMG, de Jong HJI, Carter V, Skinner D, Price D. Distribution, temporal stability and appropriateness of therapy of patients with COPD in the UK in relation to GOLD 2019. EClinicalMedicine. 2019;14:32-41.

8. Barrecheguren M, Monteagudo M, Ferrer J, Borrell E, Llor C, Esquinas C, et al. Treatment patterns in COPD patients newly diagnosed in primary care. A population-based study. Respir Med. 2016;111:47-53.

9. Calle Rubio M, Rodríguez Hermosa JL, Soler-Cataluña JJ, López-Campos $J$, Alcazar Navarrete B, Soriano JB, et al. Medical care according to risk level and adaptation to Spanish COPD guidelines (GesEPOC): the Epoconsul study. Arch Bronconeumol. 2018;54(5):270-9.

10. Miravitlles M, Cosio BG, Arnedillo A, Calle M, Alcazar-Navarrete B, Gonzalez C, et al. A proposal for the withdrawal of inhaled corticosteroids in the clinical practice of chronic obstructive pulmonary disease. Respir Res. 2017;18(1):198.

11. Avdeev S, Aisanov Z, Arkhipov V, Belevskiy A, Leshchenko I, Ovcharenko $\mathrm{S}$, et al. Withdrawal of inhaled corticosteroids in COPD patients: rationale and algorithms. Int J Chron Obstruct Pulmon Dis. 2019;14:1267-80.

12. Micheletto C, Braido F, Contoli M, Di Marco F, Santus P. A framework for step down or therapeutic re-organization for withdrawal of inhaled corticosteroids in selected patients with COPD: a proposal for COPD management. Int J Chron Obstruct Pulmon Dis. 2019;14:2185-93.

13. Kaplan AG. Applying the wisdom of stepping down inhaled corticosteroids in patients with COPD: a proposed algorithm for clinical practice. Int J Chron Obstruct Pulmon Dis. 2015;10:2535-48.

14. Nici L, Mammen MJ, Charbek E, Alexander PE, Au DH, Boyd CM, et al. Pharmacologic management of chronic obstructive pulmonary disease. An official American Thoracic Society clinical practice guideline. Am J Respir Crit Care Med. 2020;201 (9):e56-69.

15. Chalmers JD, Laska IF, Franssen FME, Janssens W, Pavord I, Rigau D, et al. Withdrawal of inhaled corticosteroids in chronic obstructive pulmonary disease: a European Respiratory Society guideline. Eur Respir J. 2020; 55

16. D'Urzo A, Donohue JF, Kardos P, Miravitlles M, Price D. A re-evaluation of the role of inhaled corticosteroids in the management of patients 
with chronic obstructive pulmonary disease. Expert Opin Pharmacother. 2015;16(12):1845-60.

17. Hurst JR, Vestbo J, Anzueto A, Locantore N, Müllerova H, Tal-Singer R, et al. Susceptibility to exacerbation in chronic obstructive pulmonary disease. N Engl J Med. 2010;363:1128-38.

18. Izquierdo JL, Morena D, González Y, Paredero JM, Pérez B, Graziani D, Gutiérrez M, Rodríguez JM. Clinical management of COPD in a real-world setting. A Big Data analysis. Arch Bronconeumol. 2020. https://doi. org/10.1016/j.arbres.2019.12.025 (Online ahead of print).

19. Miravitlles M, Monteagudo M, Solntseva I, Alcázar B. Blood eosinophil counts and their variability and risk of exacerbations in COPD: a population-based study. Arch Bronconeumol. 2021;57(1):13-20.

20. Chalmers JD, Poole C, Webster S, Tebboth A, Dickinson S, Gayle A. Assessing the healthcare resource use associated with inappropriate prescribing of inhaled corticosteroids for people with chronic obstructive pulmonary disease (COPD) in GOLD groups A or B: an observational study using the Clinical Practice Research Data. Respir Res. 2018;19(1):63.

21. Cataldo D, Derom E, Liistro G, Marchand E, Ninane V, Peche R, et al. Overuse of inhaled corticosteroids in COPD: five questions for withdrawal in daily practice. Int J Chron Obstruct Pulmon Dis. 2018;13:2089-99.

22. Nadeem NJ, Taylor SJC, Eldridge SM. Withdrawal of inhaled corticosteroids in individuals with COPD - a systematic review and comment on trial methodology. Respir Res. 2011;12:107.

23. Magnussen H, Disse B, Rodriguez-Roisin R, Kirsten A, Watz H, Tetzlaff K, et al. Withdrawal of inhaled glucocorticoids and exacerbations of COPD. N Engl J Med. 2014;371(14):1285-94.

24. Magnussen $H$, Tetzlaff K, Bateman ED, Watz $H$, Kirsten AM, Wouters $E F$, et al. Lung function changes over time following withdrawal of inhaled corticosteroids in patients with severe COPD. Eur Respir J. 2016;47(2):651-4.

25. Watz $\mathrm{H}$, Tetzlaff $\mathrm{K}$, Wouters EFM, Kirsten $\mathrm{A}$, Magnussen $\mathrm{H}$, Rodriguez-Roisin $\mathrm{R}$, et al. Blood eosinophil count and exacerbations in severe chronic obstructive pulmonary disease after withdrawal of inhaled corticosteroids: a post-hoc analysis of the WISDOM trial. Lancet Respir Med. 2016;4(5):390-8.

26. Chapman KR, Hurst JR, Frent S-M, Larbig M, Fogel R, Guerin T, et al. Long-term triple therapy de-escalation to indacaterol/glycopyrronium in patients with chronic obstructive pulmonary disease (SUNSET): a randomized, double-blind, triple-dummy clinical trial. Am J Respir Crit Care Med. 2018;198(3):329-39.

27. Rossi A, Guerriero M, Corrado A, OPTIMO/AIPO Study Group. Withdrawal of inhaled corticosteroids can be safe in COPD patients at low risk of exacerbation: a real-life study on the appropriateness of treatment in moderate COPD patients (OPTIMO). Respir Res. 2014;15(1):77.

28. Vogelmeier C, Worth H, Buhl R, Criée CP, Lossi NS, Mailänder C, et al. "Reallife" inhaled corticosteroid withdrawal in COPD: a subgroup analysis of DACCORD. Int J Chron Obstruct Pulmon Dis. 2017;12:487-94.

29. Oshagbemi OA, Franssen FME, van Kraaij S, Braeken DCW, Wouters EFM, Maitland-van der Zee AH, et al. Blood eosinophil counts, withdrawal of inhaled corticosteroids and risk of COPD exacerbations and mortality in the clinical practice research datalink (CPRD). COPD. 2019;16(2):152-9.

30. Jo T, Yasunaga H, Yamauchi Y, Mitani A, Hiraishi Y, Hasegawa W, et al. Inhaled corticosteroid withdrawal may improve outcomes in elderly patients with COPD exacerbation: a nationwide database study. ERJ Open Res. 2020;6(1):00246-2019.

31. Harries TH, Gilworth G, Corrigan CJ, Murphy PB, Hart N, Thomas M, et al. Inhaled corticosteroids prescribed for COPD patients with mild or moderate airflow limitation: who warrants a trial of withdrawal? Int J Chron Obstruct Pulmon Dis. 2019;14:3063-6.

32. López-Campos JL, Carrasco-Hernández L, Román Rodríguez L, QuintanaGallego E, Carmona Bernal C, Alcázar NB. The clinical implications of triple therapy in fixed-dose combination in COPD: from the trial to the patient. Arch Bronconeumol. 2020;56(4):242-8.

33. Bloom Cl, Douglas I, Usmani OS, Quint JK. Inhaled corticosteroid treatment regimens and health outcomes in a UK COPD population study. Int J Chron Obstruct Pulmon Dis. 2020;15:701-10.

34. Monteagudo M, Nuñez A, Solntseva I, Dhalwani N, Booth A, Barrecheguren $\mathrm{M}$, et al. Treatment pathways before and after triple therapy in COPD: a population-based study in Primary Care in Spain. Arch Bronconeumol. 2020. https://doi.org/10.1016/j.arbres.2020.07.032 (Online ahead of print).

35. Lee SH, Lee JH, Yoon HI, Park HY, Kim TH, Yoo KH, et al. Change in inhaled corticosteroid treatment and COPD exacerbations: an analysis of realworld data from the KOLD/KOCOSS cohorts. Respir Res. 2019;20(1):62.

36. Suissa S, Coulombe J, Ernst P. Discontinuation of inhaled corticosteroids in COPD and the risk reduction of pneumonia. Chest. 2015;148(5):1177-83.

\section{Publisher's Note}

Springer Nature remains neutral with regard to jurisdictional claims in published maps and institutional affiliations.
Ready to submit your research? Choose BMC and benefit from:

- fast, convenient online submission

- thorough peer review by experienced researchers in your field

- rapid publication on acceptance

- support for research data, including large and complex data types

- gold Open Access which fosters wider collaboration and increased citations

- maximum visibility for your research: over $100 \mathrm{M}$ website views per year

At BMC, research is always in progress.

Learn more biomedcentral.com/submissions 